\title{
Composting as an Eco-Friendly Method to Recycle Organic Waste
}

\author{
Santosh Narayan Chadar*1, Keerti Chadar ${ }^{2}$ and Manju Singh ${ }^{1}$ \\ ${ }^{1}$ Department of Chemistry, University Institute of Technology, India \\ ${ }^{2}$ Department of Education, Barkatullah Vishwavidyalaya, India \\ *Corresponding author: Santosh Narayan Chadar, Department of Chemistry, University Institute of Technology - RGPV Bhopal, India.
}

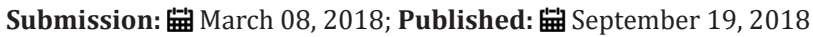

\begin{abstract}
Recycling organic matter back into the soil to improve soil structure and fertility is termed composting. It is the method for treating waste. Sanitary landfills, dumping of waste in open leads to various environmental problems and cause pollution. Composting is a method by which stabilization of waste is done for land filling, mass reduction of solid waste is done and hence in this way the waste return to the natural cycle as an organic substance. This paper reviews the information regarding the waste treating process i.e., composting in order to reduce air, water and land pollution and enhance soil fertility, it also reviews the benefits of composting and the techniques involved in it [1].
\end{abstract}

Keywords: Composting; Municipal solid waste; Pollution; Landfills; Aerobic composting; Anaerobic composting; Vermicomposting; Windrow composting

\section{Introduction}

Composting of waste involves decomposition of organic waste into humus known as a fertilizer. Compost is a key ingredient in organic farming. Compost is rich in nutrients. Traditional method of composting involves making the heaps of wet organic matter as leaves, food waste, kitchen waste, paper shredded, mixed with grass cuttings, industrial waste as food pulp and paper, sewage sludge, yard and garden waste etc. and waiting till the material gets converted into humus. It is a time-consuming process. It takes few months to get ready. Whereas the modern method of composting involves various steps and the compost is obtained within 2-3weeks. In this method the process is closely monitored [2], proper aeration is maintained. As per need water, air, carbon, and nitrogen rich material is used which enhance the process of humus formation by producing heat. Worms, fungi, bacteria, are breaking the material. All these factors help in humus formation positively. Composting is enhancing soil fertility as it acts as a soil conditioner, fertilizer, natural pesticides. The heat produced during composting destroys pathogens, the disease-causing microorganism and weed seeds [3].

\section{Types of Composting}

\section{Aerobic composting}

The composting which take place in presence of oxygen is called aerobic composting. In aerobic composting $\mathrm{CO}_{2}$, water, heat, and $\mathrm{NH}_{3}$ are produced. Any type of waste can be treated by this method when proper ingredients and conditions are present [4].

\section{Anaerobic composting}

The composting which takes place in absence of $\mathrm{O}_{2}$, Methane, $\mathrm{CO}_{2}, \mathrm{NH}_{3}$ and trace amount of other gases and organic acids are produced. This method is used to treat municipal solid waste, animal manure, and human sewage sludge [5].

\section{Techniques Involved in Composting}

\section{Industrial scale composting process}

It consists of the methods by which the compost is produced in large amount such as In-vessel composting, aerated static pile composting, vermicomposting and windrow composting.

Vermicomposting: In this method, the red wiggler earthworm or red worm are used, also

known as tiger worms. These worms' feeds on vegetable waste and kitchen scraps. They transform this waste material into highly fertile manure. Moisture contents should be maintained properly as it should not harm worms. Maintain 50-77degree Celsius temperature because at this stage the worms are at their decomposing peak [6].

Aerated static pile: Also termed as tunnel composting. It is controlled process for the fast

biodegradation of organic matter. It refers to a number of systems used to biodegrade organic material without physical 
manipulation during primary composting. It is placed on perforated piping to provide air circulation for controlled aeration. It can be done under roof or outdoor windrow composting or totally in vessel composting. It can be done in small, simple systems and to a large, capital intensive, industrial installations [7].

In vessel composting method: It consists of metal or plastic tanks or concrete bunkers

in which air flows and temperature can be controlled using the principle of bioreactor.

Windrow composting: In agriculture windrow composting method is mainly used for the

production of compost in large amount. Organic matter or biodegradable waste such as animal manure and residue are arranged in long rows.

\section{Composting Toilets}

Also termed as humanure and Eco humus. In this method human excreta are added with straws and saw dust and other carbon rich materials, where pathogens are destroyed, it depends on the temperature and composting time. In composting toilet method, the excreta are processed in situ and then it is coupled with a secondary external composting step. This method prevents pollution of ground water by controlling the faecal matter decomposition before entering the system and it also prevent ground contamination [8].

\section{Bin Composter}

In this method we don't have to turn the organic material. 30:1 ratio of brown and green component in the compost is essential. This compost matures in 3-4years as no activator is used in it.

\section{Black Soldier Fly Larvae Composting}

Black soldier fly (hermetia illucens) larvae is able to consume large amount of organic waste rapidly when kept at $31.8{ }^{\circ} \mathrm{C}$, the optimum temperature for reproduction [9].

\section{Anaerobic Composting}

This composting is done in black garbage bags, in which brown green and soil layers are made, tied very tightly and sealed. It is stored in cool place in garden and it is left free for 6-7months to mature [10].

\section{Quick Composting}

To get the compost as early as possible this method is used, it is labor intensive method as we have to turn the compost after 3-4 days and material should be of small size [11].

\section{Plain Composting Method}

It is the simple method of composting which involves the garden space of $25 \mathrm{sq} \mathrm{ft}$ for compost pit. It should be aerated. Firstly, brown organic matter has to be filled in the pit at the bottom followed by green matter and then soil. Limestone, granite dust and green sand can be sprinkled to add calcium, phosphate and potash in compost. Layers should be made till $5 \mathrm{ft}$ and they should be moistened. Keep on turning the material from time to time until compost get ready in 3-4 months [12].

\section{Effective Ingredients Required for Composting}

A. Oxygen- It oxidize carbon and hence helps in decomposition process.

B. Water- Moisture maintains decomposition activity without causing anaerobic process.

C. Nitrogen- Proper proportion of carbon and nitrogen helps in decomposition of material.

\section{Microorganisms}

A. Actinobacteria helps to break bark or papers.

B. Protozoa reduces bacteria, fungi and organic particulates by consuming it.

C. Rotifers maintain the bacteria and protozoan content in humus [13].

D. Bacteria helps in decomposition of organic material at different levels.

E. Fungi such as yeast and moulds helps to enhance decomposition process [14].

\section{Benefits of Composting}

\section{Pathogen removal}

Various pathogen or unwanted seeds can be destroyed by composting. Red worms also help in reducing pathogens [15].

\section{Enrich soil}

It is used as an additive in soil. It provides a rich growing medium, or a porous absorbent material that holds moisture and soluble materials, provide strength and nutrients to plants. It helps in soil conditioning [16].

\section{Economical}

Composting process is economical as it saves money; its process does not require much money [17].

\section{Alternative for landfilling}

Composting is considered as a good alternative to landfilling [18].

\section{Practical and convenient}

Composting is a practical and a convenient method to use and prepare both [19].

\section{Healthier plant}

A healthier plant can be obtained as the soil is enriched by the organic compost [20]. It can be used in dressing lawns, flower 
gardens, kitchen garden, vegetable garden, trees and shrubs, house plants, gardens, farm fields etc.

\section{Conclusion}

Composting is an ecofriendly method of treating waste which convert the organic waste into useful product, it reduces the mass of solid waste and help to control pollution i.e., land, water and air. Composting has various advantages as it is economical, convenient and helps in landfilling. It enriches soil and removes pathogen from soil. All the techniques of composting ultimately lead to waste treatment and convert it into the useful product [21]..

\section{References}

1. James IC, Tin EH (2008) Effects of composting on waste composting. Bioresour Technol 99(12): 8068-8074.

2. Fauziah SH, Agamuthu P (2009) Sustainable household organic waste management via Vermicomposting. Malaysian Journal of Science 28(2): 135-142.

3. Kashmanian RM, Rynk R (1995) Agricultural composting in the United States. Compost Science and Utilization 3(3): 84-88.

4. Smith A, Brown K, Ogilvie S, Rushton K, Bates J (2009) Waste management options and climate change. Final report to the European commission, DG Environment, European communities 1(1): 1-224.

5. Vander GJS, Pettygrove S, Dooley TM, Arnold KA (2004) Estimating electrical conductivity of compost extracts at different extraction ratios. Compost science and utilization 12(3): 202-207.

6. UN (1998) Kyoto protocol to the united nations framework. Convention on climate change. United Nations, pp. 1-21.

7. Gilbert MM, Wendell PE (1997) Introduction to environmental engineering and science. ( $3^{\text {rd }}$ edn), Prentice Hall, USA.
8. Edward CA (1998) Earthworm ecology. CRC Press LLC, USA, pp. 189.

9. Palaniappan SP, Annadurai K (2006) Organic farming: theory and practices. Scientific publishers, Jodhpur, India, p. 256.

10. Ndegwa PM, Thompson SA (2001) Integrating composting and vermicomposting in the treatment and bioconversion of biosolids. Bioresour Technol 76(2): 107-112.

11. Hang Roger (2015) The practical handbook of compost engineering. $\left(1^{\text {st }}\right.$ edn), CRC Press, India, p. 752.

12. Aubin (2010) The case for mandatory composting. The boston globe, San Fransisco, USA.

13. Lazcano C, Gomez BM, Dominguez J (2008) Comparison of the effectiveness of composting and vermicomposting for the biological stabilization of cattle manure. Chemosphere 72(7): 1013-1019.

14. Belay A, Claassens AS, Wehner FC (2002) Effect of direct nitrogen and potassium and residual phosphorous fertilizers on soil chemical properties, microbial components and maize yield under long term crop rotation. Biology and Fertility of Soils 35(6): 420-427.

15. Cantrell KB, Ducey T, Ro KS, Hunt PG (2008) Livestock waste-tobioenergy generation opportunities. Biores Technol 99(17): 7941-7953.

16. Asthegardenturns.com (2016) How to make compost at home.

17. Michael Allan M (2012) Cleaning up heavy metals using worms.

18. Edwards Clive A (2010) Vermiculture technology. CRC Press, USA, pp. 392-406.

19. San Francisco (2010) Signs mandatory recycling and composting laws.

20. Chen R, Li R, Deitz L, Yan Liu Y, Stevenson RJ, et al. (2012) Freshwater algal cultivation with animal waste for nutrient removal and biomass production. Biomass Bioenergy 39: 128-138.

21. Vijay VK (2011) Biogas enrichment and bottling technology for vehicular use. Biogas forum 1(1): 12-15.
Creative Commons Attribution 4.0 International License

For possible submissions Click Here

\section{Submit Article}

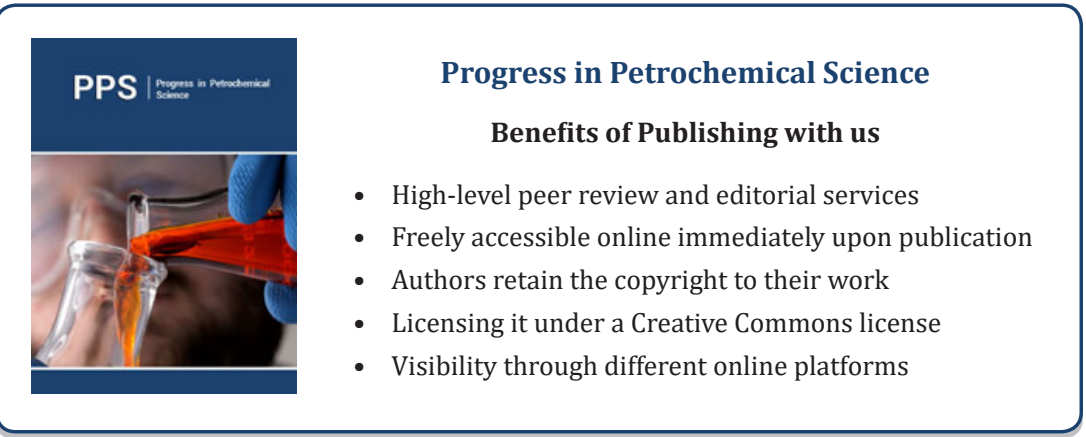

